Article

\title{
Livestock and Small-Scale Irrigation Scheme Interactions as a Key Source for Sedimentation during the Irrigation Season: Four Case Studies from South-West Shoa, Ethiopia
}

\author{
Hanan Tadele Dessalegn ${ }^{1, *}$, Alex Bolding ${ }^{2}$, Charlotte de Fraiture ${ }^{2,3}$ and Mekonen Ayana 4 (D) \\ 1 Faculty of Hydraulic and Water Resources Engineering, Arba Minch University, \\ Arba Minch P.O. Box 21, Ethiopia \\ 2 Water Resources Management Group, Wageningen University, Droevendaalsesteeg 3a, \\ 6708 PB Wageningen, The Netherlands; alex.bolding@wur.nl (A.B.); c.defraiture@un-ihe.org (C.d.F.) \\ 3 Department of Water Science and Engineering, IHE Delft Institute for Water Education, Westvest 7, \\ 2611 AX Delft, The Netherlands \\ 4 Department of Water Resources Engineering, Adama Science and Technology University, \\ Adama P.O. Box 1888, Ethiopia; mekonen.ayana24@gmail.com \\ * Correspondence: hanantadele.dessalegn@wur.nl
}

\section{check for} updates

Citation: Dessalegn, H.T.; Bolding, A.; Fraiture, C.d.; Ayana, M.

Livestock and Small-Scale Irrigation Scheme Interactions as a Key Source for Sedimentation during the Irrigation Season: Four Case Studies from South-West Shoa, Ethiopia.

Sustainability 2021, 13, 5745 .

https://doi.org/10.3390/su13105745

Academic Editor: Mohammad Valipour

Received: 9 April 2021

Accepted: 16 May 2021

Published: 20 May 2021

Publisher's Note: MDPI stays neutral with regard to jurisdictional claims in published maps and institutional affiliations.

Copyright: (c) 2021 by the authors. Licensee MDPI, Basel, Switzerland. This article is an open access article distributed under the terms and conditions of the Creative Commons Attribution (CC BY) license (https:// creativecommons.org/licenses/by/ $4.0 /)$.

\begin{abstract}
Small-scale irrigation (SSI) development can play a major role in Ethiopia's economic development, but sedimentation is a major threat to its sustainability. The focus of the dominant discourse around the sedimentation of SSI schemes lies in upstream catchment protection during the rainy season, neglecting both protection against erosion through overland flow along the margins of the canal network and sedimentation caused by livestock disturbances. Remedies against the latter causes of sedimentation during the irrigation season have been ineffective due to erroneous assumptions regarding its cause. This study aimed to identify the sources and extent of sedimentation in SSI schemes. The accumulated sediment in the canal pre-irrigation season was measured from four SSI schemes and suspended sediment samples during irrigation season were collected from one SSI scheme. The accumulated sediment in the canal pre-irrigation season was measured from four SSI and suspended sediment samples during irrigation season were collected from one SSI scheme. The extent of sedimentation in the canals during the pre-irrigation season in relation to canal capacity was $100 \%$ of lined and unlined canals in abandoned, $68 \%$ in a lined, and $84 \%$ unlined canals in heavily sedimented and $38 \%$ in a lined and $46 \%$ of unlined canals lightly sedimented schemes. Livestock interactions with the SSI schemes were found to be the major sediment source before and during the irrigation, hence, attention should be given to integrating livestock as a part of the system.
\end{abstract}

Keywords: small-scale irrigation scheme; sedimentation; livestock access; sediment cause

\section{Introduction}

Irrigation development plays a major role in Ethiopia's economic development program [1]. Investments in irrigation infrastructure and the maintenance of irrigation schemes are key to improve agricultural productivity and fast-track economic growth for practical poverty reduction [2]. Irrigation schemes in Ethiopia are classified based on the size of their command area into three types [1], namely, small-scale ( $<200$ hectares), medium-scale (200-3000 hectares), and large-scale irrigation systems (>3000 hectares). Small-scale irrigation plans have been identified as vital to ensure the food security of the nation because of their simplicity to develop and operate, relatively small investment, and cheap operation and maintenance [3]. Despite huge ambitions, $80 \%$ of the proposed irrigation development in Ethiopia falls within the small-scale irrigation category.

In Ethiopia, most irrigation schemes do not operate at full capacity and many of the schemes fail to serve the purpose for which they are intended [3-5]. In Oromia Regional State alone, 109 (18\%) of the modern irrigation schemes and 8508 (13\%) of the pumped 
irrigation schemes were reported to be inoperative or semi-functional in 2017 [6]. In the Tigray region, most of the reservoirs that feed the small-scale irrigation schemes are filled with sediment within less than $50 \%$ of their intended service time [7].

Improvement of this low performance is high on the policy agenda and the prime motivation of the government to keep investing in the sector. The causes of underperformance and abandonment of the schemes are often diverse and complex; one of the major constraints is excessive sedimentation in the headworks and canal network and a lack of available funds and skilled manpower for operation and maintenance $[4,8]$. In a developing country like Ethiopia, rapid population growth, deforestation, uncontrolled land use, and overgrazing have resulted in accelerated soil erosion [9]. Soil erosion and soil loss are major challenges for sustainable irrigated agricultural development.

Excessive sedimentation in irrigation schemes can cause clogging of the intake, filling the headworks and canals, and jamming of the sluice gates, which in turn causes inequity and inadequacy in water supply $[5,10,11]$. The management of sedimentation in irrigation schemes requires a considerable budget and manpower to keep up the canals. However, problems related to the accessibility of funds or labour often cause a considerable delay in maintenance, and may ultimately lead to the abandoning of the schemes [10]. Therefore, the planned food security improvement may be under threat unless relevant preventive measures are put in place.

Most of the existing studies point to the soil erosion in the upper and middle river catchment as a prime cause of sedimentation, whereby high sediment loads pass through the intake structure of irrigation schemes and accumulate in the (unlined) canal network, thus resulting in excessive sedimentation [12-15]. Other studies have documented that the causes of sedimentation vary according to different stakeholders' perceptions [6]; some ascribe sedimentation to design problems, most engineers identify soil erosion in the upstream river catchment and a lack of appropriate technology and materials as prime causes, and farmers see poor operation and maintenance as a major cause.

Some scholars argue that cattle accessing streams, grazing, and trampling of stream banks cause an increase in soil erosion, destruction of in-stream banks, and changes to stream morphology [16-18]. Overgrazing puts serious pressure on the natural environment. It is a known desertification driver $[17,19,20]$, showing that the livestock sector has a negative impact on water depletion and pollution from grazing and feed crop production. The powerful locomotive efforts of cattle, including the incisional and erosive forces of cattle hooves, coupled with overgrazing can result in a reduction in stream bank stability [21] and increase suspended sediment and turbidity [22] that leads to the contribution of local levels of in-stream deposited sediment [23]. Even though some studies point to livestock accessing the grazing land on the canal bank as potential sediment sources, most literature focuses on the sedimentation caused during the rainy season. In Ethiopia, the sediment management strategy established in irrigation schemes is ineffective because it considers only the sediment source during the rainy season. It focuses on watershed management as a solution, but sedimentation during the rainy season is not the only cause. Identification of the main cause of sedimentation year-round is the first step in determining effective solutions. Therefore, this study aims to identify the causes and extent of sedimentation in four small-scale irrigation schemes. It is argued that livestock-irrigation interactions are the main sediment source before and during the irrigation season.

The paper consists of seven sections; the next section introduces different discourses of sediment causes. Section 3 introduces the key features of the study areas. Section 4 describes the study methods. Section 5 presents the results of the extent and origin of sedimentation in the four study schemes while delving deeper into the dynamics of sedimentation during one whole irrigation season in one case study scheme. Section 6 assesses the importance of different causes for sedimentation, identifying livestock interactions as the key in-season cause, and delving deeper into the drivers behind livestock-irrigation interactions. The last section presents the overall conclusion and some policy recommendations for tackling sedimentation during the irrigation season. 


\section{Discourses on the Causes of Sedimentation in SSI Schemes}

There are two dominant discourses on the causes of sedimentation in small-scale irrigation schemes: soil erosion in the upstream watershed (the neo-Malthusian discourse) and improper design of small-scale irrigation (the faulty design discourse).

Many authors identify the upstream catchment soil erosion and the high rates of soil erosion and land degradation in Ethiopia as major drivers of sedimentation in irrigation systems. An estimated $25 \%$ of the highland area is affected by large volumes of soil eroded annually. Soil erosion and soil loss are major challenges for sustainable agricultural development in the Ethiopian highlands. Inappropriate agricultural practices, high population pressure from humans and livestock, high rainfall intensity, and rugged topography have been reported as the main facilitators of severe soil erosion and sedimentation [8]. Soil erosion in the upper and middle catchment is the main source of sedimentation during the rainy season [13]. The sediment-laden river water that comes from the upstream eroded catchment is seen in this discourse as the main sediment source clogging irrigation systems [12]. Deforestation also contributes to upstream soil erosion, and watershed management is seen as a fundamental step to reduce sedimentation [7].

The second discourse around causes of sediment problems in irrigation highlights the poor design of small-scale irrigation schemes without considering adequate baseline data [13,24]; faulty design and location of the intake; mild longitudinal slopes; poor layout of the main canal; and poor operation and maintenance [6]. One of the causes of sedimentation is the soil erosion of the unlined canals due to the erosive potential of the irrigation water flowing through thecanal [12]. This discourse implies that proper design of the infrastructure and better operation and maintenance is needed to reduce the sedimentation.

The two dominant discourses are propagated by different professional groups, namely policymakers and engineers. Considering the ineffectiveness of the proposed sediment management solutions and the vital role of the mitigation measures, a deeper understanding of the extent and causes of the sedimentation is warranted. Therefore, we researched four small-scale irrigation schemes in different settings and with variables rates of sedimentation. Based on this deeper understanding, we will propose a third discourse that accords a prime role to livestock-SSI interactions, thus allowing us to recommend more effective measures to control and mitigate the problem of sedimentation in SSI schemes in our concluding section.

\section{Description of the Study Areas}

\subsection{Selection of Case Study Schemes}

This study was conducted in the south-west Shoa zone of Oromia, Waliso, and Ameya districts, which are located between 110-158 km from the capital city of Ethiopia, Addis Ababa, along the main road to Jimma. Four small-scale irrigation schemes were purposively selected (Figure 1) based on three sets of criteria. Firstly, all schemes had to meet the criteria of proximity and accessibility. Secondly, a variety in the degree of sedimentation varying from light to heavy sediment loads was required, whereby the Boye 1 and 2 merged scheme represents the lightly sedimented category and the Ejersa small-scale irrigation scheme represents the heavily sedimented category. Thirdly, this study probed what happens when a scheme is abandoned due to sedimentation, including both an abandoned scheme (Meri-Megari) and a new scheme that was started in response to abandonment (Kulit) in the same location. Hence, four schemes were selected, of which three are functional schemes and one is a non-functional scheme. 


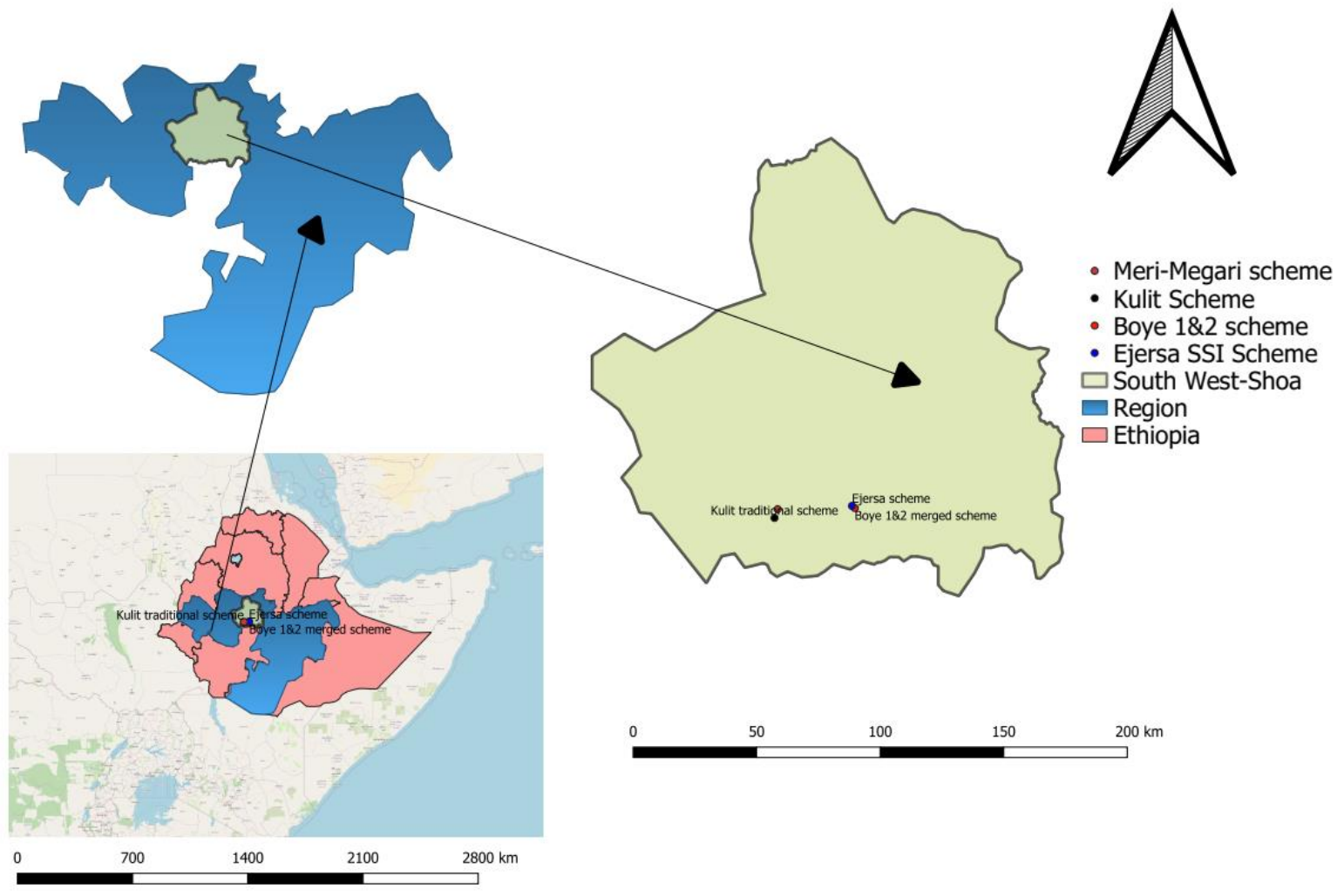

(A)
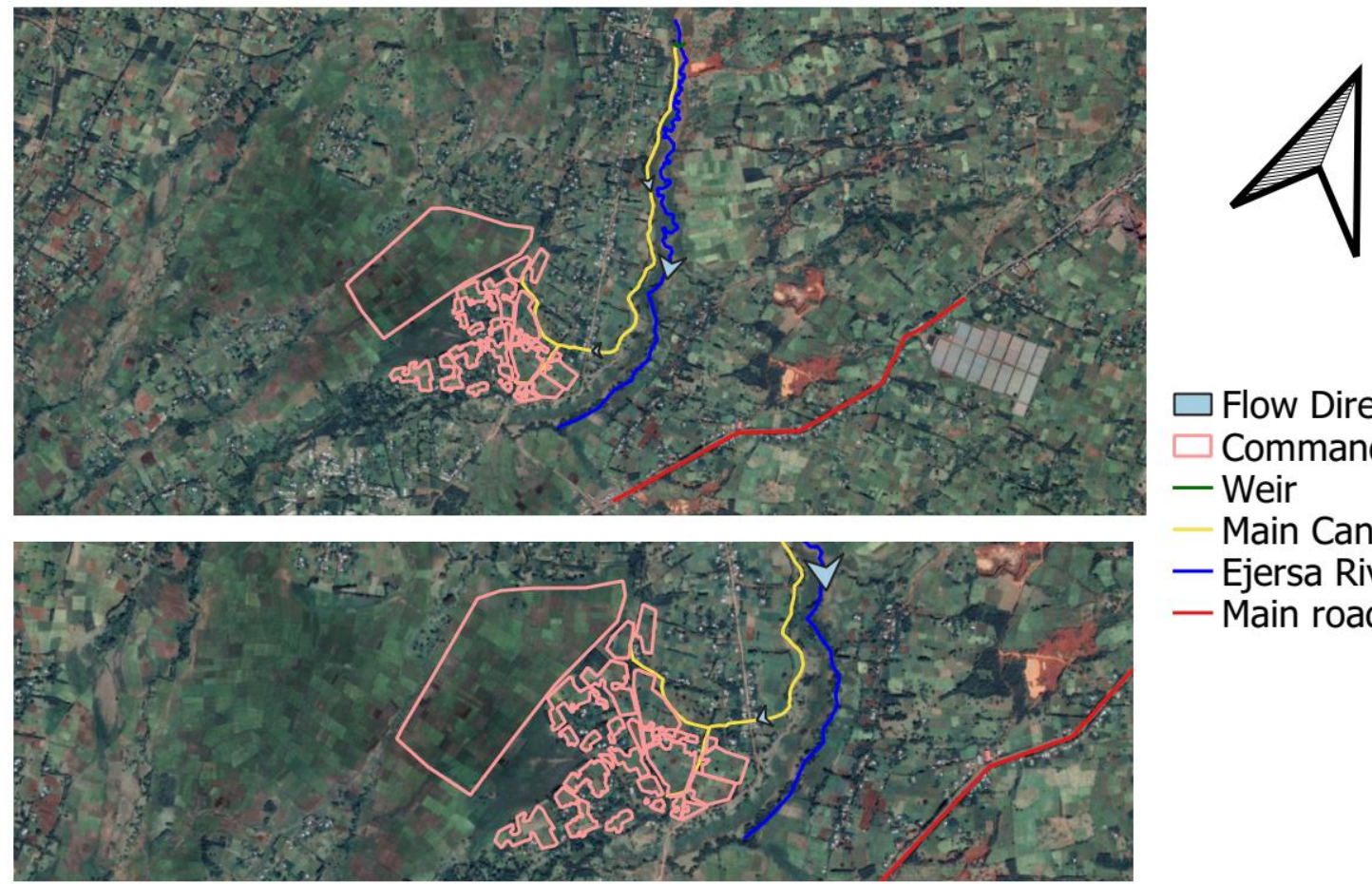

$\square$ Flow Direction

$\square$ Command Area

- Weir

- Main Canal

- Ejersa River

- Main road

0

700

1400

2100

$2800 \mathrm{~m}$

(B)

Figure 1. Cont. 

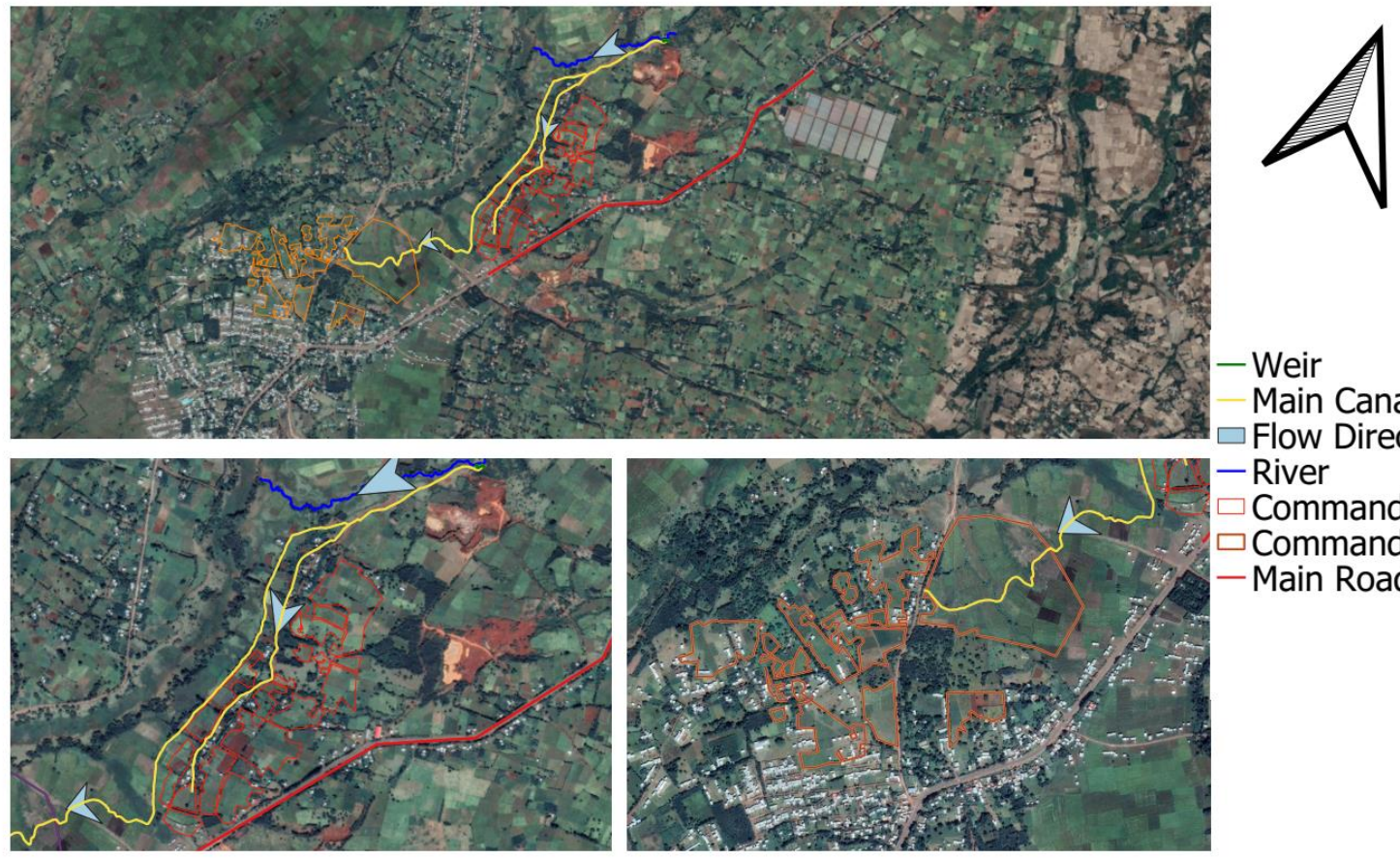

- Weir
Main Canal
Flow Direction

- River

$\square$ Command Area 1

$\checkmark$ Command Area 2

- Main Road
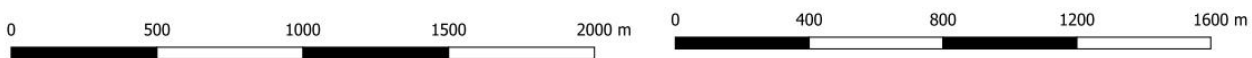

(C)
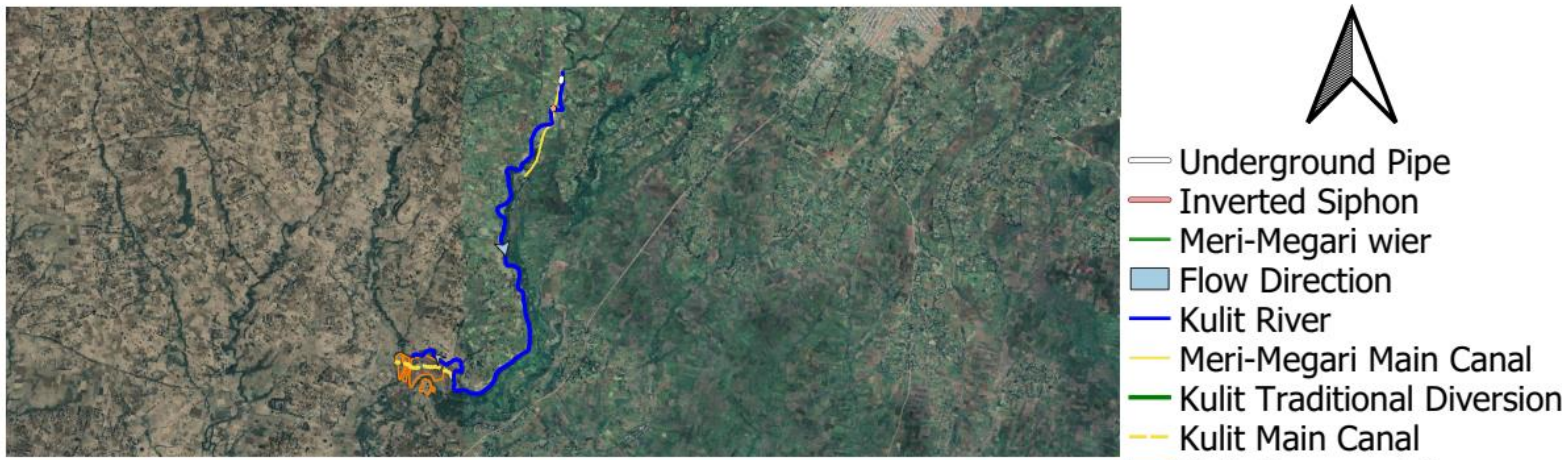

Meri-Megari Scheme Kulit Scheme Kulit Command Area
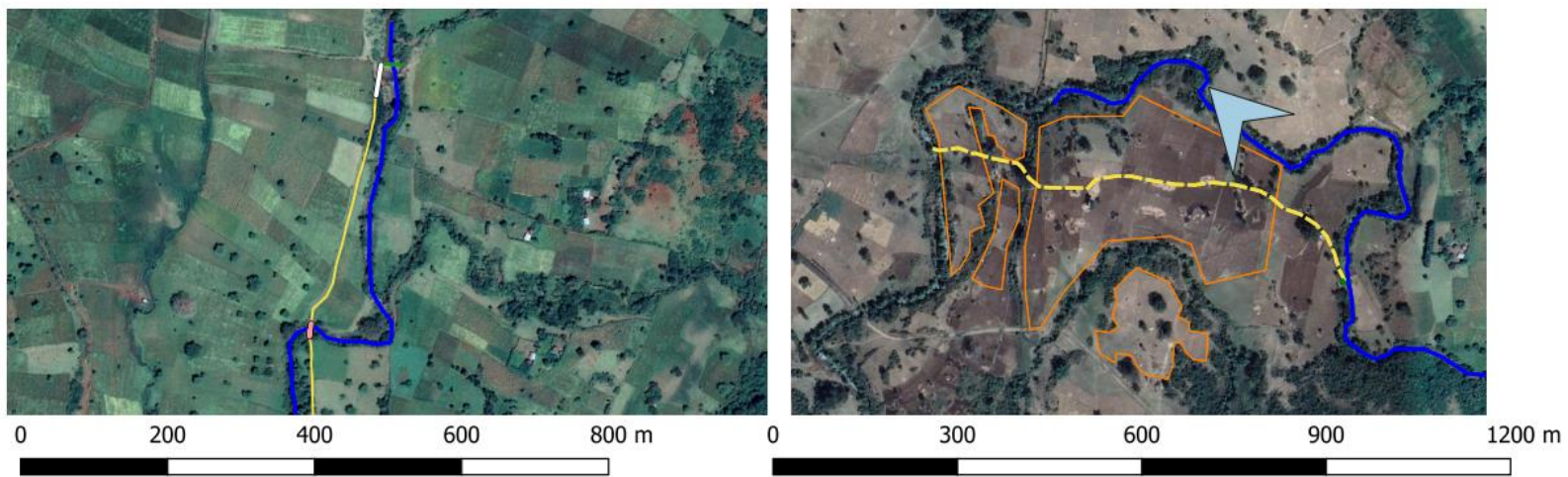

(D)

Figure 1. (A) Location of the study area with the four case study irrigation schemes. (B) Ejersa small-scale irrigation scheme. (C) Boye 1 and 2 merged small-scale irrigation schemes. (D) Meri-Megari scheme and Kulit traditional small-scale irrigation scheme. (Source: Hanan Tadele, own material.) 


\subsection{Background Information of Each Study Scheme}

In Ethiopia, small-scale irrigation schemes are divided into different categories based on the establishment, management, and nature of the structure. Traditional irrigation schemes usually use temporary diversion arrangements or barriers made from local material which need annual maintenance. The canals are usually earthen, and the schemes are managed by the community. Modern schemes are irrigation systems with more permanent diversion weirs made from concrete that do not require annual re-construction. They are mostly community-managed, and the primary and secondary channels are made of concrete. Modernized schemes are traditional schemes that were upgraded after some time with more permanent diversion and concrete canals [25].

The Ejersa small-scale irrigation scheme was modernized with the support of the government but is now a heavily sedimented scheme that serves two kebeles (the lowest administrative unit in the country), Dembeleketa and Bedesa Koricha. It is located $114 \mathrm{~km}$ from Addis Ababa along the highway to Jimma at an average elevation of $2120 \mathrm{~m}$ above mean sea level, covering 96 hectares of command area, providing water for 120 households (Table 1).

Table 1. Background information on the selected small-scale irrigation schemes.

\begin{tabular}{|c|c|c|c|c|c|c|c|c|c|c|}
\hline S. No & $\begin{array}{l}\text { Irrigation } \\
\text { Schemes }\end{array}$ & Location & $\begin{array}{l}\text { Type of } \\
\text { Scheme }\end{array}$ & $\begin{array}{l}\text { Command } \\
\text { Area } \\
\text { Hectare } \\
\text { (ha) }\end{array}$ & $\begin{array}{l}\text { No. of } \\
\text { Beneficia- } \\
\text { ries }\end{array}$ & $\begin{array}{l}\text { Year of } \\
\text { First Op- } \\
\text { eration }\end{array}$ & $\begin{array}{c}\text { Mean } \\
\text { Annual } \\
\text { Rainfall } \\
(\mathrm{mm})\end{array}$ & $\begin{array}{c}\text { Water } \\
\text { Sources }\end{array}$ & $\begin{array}{l}\text { Irrigation } \\
\text { Methods }\end{array}$ & $\begin{array}{l}\text { State of the } \\
\text { Scheme }\end{array}$ \\
\hline 1 & $\begin{array}{c}\text { Boye } 1 \& 2 \\
\text { merged } \\
\text { scheme }\end{array}$ & $\begin{array}{c}\text { Waliso } \\
\text { Woreda }\end{array}$ & Upgraded & 56 & 121 & 2013 & 1208 & $\begin{array}{l}\text { Boye } \\
\text { River }\end{array}$ & $\begin{array}{l}\text { Furrow } \\
\text { Irrigation }\end{array}$ & $\begin{array}{c}\text { Lightly } \\
\text { sedimented }\end{array}$ \\
\hline 2 & $\begin{array}{c}\text { Ejersa } \\
\text { scheme }\end{array}$ & $\begin{array}{l}\text { Waliso } \\
\text { Woreda }\end{array}$ & Upgraded & 96 & 120 & 2013 & 1200 & \multirow{3}{*}{$\begin{array}{l}\text { Ejersa } \\
\text { River } \\
\text { Kulit } \\
\text { River } \\
\text { Kulit } \\
\text { River }\end{array}$} & $\begin{array}{l}\text { Furrow } \\
\text { Irrigation }\end{array}$ & \multirow{3}{*}{$\begin{array}{c}\text { Heavily } \\
\text { sedimented } \\
\text { Lightly } \\
\text { sedimented } \\
\text { Abandoned } \\
\text { since } 2016\end{array}$} \\
\hline 3 & Kulit scheme & $\begin{array}{l}\text { Ameya } \\
\text { Woreda }\end{array}$ & Traditional & 17 & 29 & 2019 & 1270 & & $\begin{array}{l}\text { Furrow } \\
\text { Irrigation }\end{array}$ & \\
\hline 4 & Meri-Megari & $\begin{array}{l}\text { Ameya } \\
\text { Woreda }\end{array}$ & Modern & 200 & 234 & 2000 & 1270 & & & \\
\hline
\end{tabular}

Boye 1 and 2 began operation as two separate traditional small-scale irrigation schemes and were later merged and modernized by the government without the irrigation users consent. The modernization entailed improvements to the new main intake and the lining of the main canal. This scheme was selected as representative of lightly sedimented schemes. It is located $110 \mathrm{~km}$ from Addis Ababa, at an average elevation of $2123 \mathrm{~m}$ above mean sea level. The present scheme comprises two parts: Boye 1, providing water to 56 households, and Boye 2, providing water to 65 households, irrigating a total command area of 56 hectares.

Meri-Megari was a modern small-scale irrigation scheme that is now non-functional (abandoned). The main causes of its abandonment are sedimentation and excessive seepage loss along the canal. It is located at $158 \mathrm{~km}$ from Addis Ababa, at an average elevation of $1902 \mathrm{~m}$ above mean sea level. Before abandonment, it comprised 200 hectares of command area, providing water for 234 households.

The Kulit traditional small-scale irrigation scheme was selected as a scheme that was initiated and constructed by some of the same farmers who were previously using the Meri-Megari modern scheme until its abandonment. A traditional weir in Kulit was constructed at $5.3 \mathrm{~km}$ downstream from the Meri-Megari abandoned scheme weir. It is located $151 \mathrm{~km}$ from Addis Ababa, at an average elevation of $1834 \mathrm{~m}$ above mean sea level, and comprising 17 hectares of command area, providing water for 29 households.

\subsection{Climate and Weather Condition of the Study Areas}

All selected schemes are situated in the Woyna-Dega (mid-highland) agro-ecological zone. Its rainfall pattern is of the unimodal type in which one main rainy season occurs during summer, which lasts from June to August. The mean annual rainfall of the area 
ranges from 1208 to $1270 \mathrm{~mm}[26,27]$. The average temperature of the study area undulates between 26.7 in summer and $10.3^{\circ} \mathrm{C}$ in winter.

\section{Materials and Methods}

\subsection{Methods of Data Collection}

As a general methodological approach, we used a "follow the water" approach to identify and map the water users and their networks, to map all relevant infrastructure and institutions, along with a "follow the livestock" approach to assess the uses of livestock, the grazing areas around the schemes, track livestock owners, and analyze the problem of the livestock-irrigation interaction. We selected the participants for a qualitative interview using a purposive and snowball sampling technique to identify the key informants from the head, middle, and tail-end users who represent the range of variation expected in the water user population. The fieldwork was conducted during two periods: from June to October 2018 and from September 2019 to February 2020. We conducted open-ended and semi-structured in-depth interviews with older farmers, Water User Association (WUA) committee members, irrigation users, livestock farmers (LF), selected professionals, and relevant government officials. The number of interviewees was expanded until the collected information reached a certain saturation level, when no new insights could be collected beyond those that had already been expressed [28,29]. Field observations provided firsthand information on the irrigation schemes' operation and maintenance practices and the schemes' interaction with the livestock and the livestock farmers. We gathered secondary data from the district and a regional office that have had a stake in the respective schemes, and we conducted nine focus group discussions on the topic with six to eight participants in each session.

We interviewed 75 persons in total: 18 women and 45 men farmers spread across the head, tail, and middle-reaches of the four schemes, including WUA and LFA committee members. Twelve officials also interviewed, of which five were irrigation development agents (DA); one was a former DA from Waliso woreda, two were active DAs from Waliso woreda, and two were DAs from Ameya woreda. Four government officials were also interviewed-one from Oromia irrigation development agency in Addis Ababa, one from Waliso woreda, one from the Ameya woreda office, and one from the south-west Shoa province. Finally, three engineers were interviewed-one from Oromia irrigation development agency in Addis Ababa and two from the south-west Shoa province. The age of the respondents ranged from 14 to 79 years.

\subsection{Accumulated Sediment and Sediment Inflow Data Collection}

The accumulated sediment in the canals before the beginning of the irrigation season was measured in the Boye 1 and 2 and Ejersa schemes for one season by using a staff rod with a flat sheet at the bottom of the rod to measure the depth of accumulated sediment and depth of both lined and unlined canals. The bottom flat sheet helped to prevent the staff rod from penetrating the surface of the unlined canal. Since the deposited sediment in the canal were non-uniformly distributed, we measured the accumulated depth in three places (left, right, and middle of the canal) in all data collection points and we took the average value. The canal profile was established by using a measuring tape to determine the width and length of the canal. The volume of the accumulated sediment is then calculated by applying the volume equation:

$$
V_{R c}=\mathrm{L} \times \mathrm{W} \times D_{a c c}
$$

$\mathrm{V}_{\mathrm{RC}}=$ volume of accumulated sediment in rectangular canal $\left(\mathrm{m}^{3}\right)$

$\mathrm{L}=$ length of the canal that covered my accumulated sediment $(\mathrm{m})$

$\mathrm{W}=$ width of the canal $(\mathrm{m})$

$\mathrm{D}_{\mathrm{acc}}=$ accumulated sediment depth (m) 
For unlined trapezoidal canals:

$$
V_{T c}=L \times\left(B+z D_{a c c}\right) D_{a c c}
$$

$\mathrm{V}=$ volume of accumulated sediment in trapezoidal canal $\left(\mathrm{m}^{3}\right)$

$\mathrm{L}=$ length of the canal that covered my accumulated sediment $(\mathrm{m})$

$\mathrm{B}=$ bottom width of the trapezoidal canal $(\mathrm{m})$

$\mathrm{D}=$ accumulated sediment depth $(\mathrm{m})$

$\mathrm{z}=$ side slope of trapezoidal canal

To calculate the volume of canal capacity:

$$
V_{c c}=\mathrm{L} \times \mathrm{W} \times D_{c}
$$

$\mathrm{V}_{\mathrm{cc}}=$ volume of canal capacity $\left(\mathrm{m}^{3}\right)$

$\mathrm{L}=$ canal length $(\mathrm{m})$

$\mathrm{W}=$ canal width $(\mathrm{m})$

$\mathrm{D}_{\mathrm{c}}=$ canal depth $(\mathrm{m})$

Percentage of accumulated sediment

$=\frac{\text { The volume of accumulated sediment in the canal }}{\text { Canal capacity in volume }} \times 100$

\subsection{Sediment Inflow Measurements}

Sediment inflow was measured in the Ejersa scheme during one irrigation season from September 2019 to February 2020. These measurements considered the changes in discharge because of inflow in or outflow from the canal, operation of the control structure, changes in canal geometry along its length, changes in roughness when there is a different surface material of the canal, and changes in bed level. Eight data collection points were marked within the $1.85 \mathrm{~km}$ length of the main canal from the intake. All required data (water flow, cross-section, sediment concentration sample, top and bottom bed level, water depth) were measured at each section once a week. Inflow sediment was measured at the eight marked points by using a DH-48 depth-integrating sampler. Depth integrated suspended sediment sampling is carried out at one vertical point most closely representing the centroid of flow for that canal width. We took three samples from each station at a time. All samples were composited into a single container which was then agitated, sub-sampled, and analyzed for suspended sediment concentration [30], and velocity was measured by using a digital current meter. The canal cross-section and water depth were established using a measuring tape. To determine suspended sediment concentration, we used pre-weighed glass fiber filters (Whatman GF/C). After filtration of a certain volume, the filters are dried and weighed to obtain the suspended sediment concentration.

\section{Results and Discussion: Extent and Origins of Sedimentation in the Study Schemes}

Below we first present data pertaining to the extent that the four study schemes have been affected by sedimentation (5.1), then we identify the origin of this sediment (5.2), describe the livestock-irrigation scheme interaction as a sediment source (5.3), and finally we describe the suspended sediment inflow for the Ejersa irrigation scheme during the 2019-2020 irrigation season (5.4).

\subsection{The Extent of Sedimentation in All Four Schemes}

In the abandoned Meri-Megari scheme, the construction took place between 2001/2002 and 2005/2006, initially with the full potential of irrigating 200 hectares. In the first 5 years, it went from irrigating 200 hectares to a significantly reduced area of 40 ha. It was abandoned in 2016, having served only half of its designed lifetime of 20 years. The main reasons for its abandonment were sediment deposition at the intake and canal networks, and the high levels of seepage loss. In 2019, we observed and learned that the entire canal 
capacity had been $100 \%$ filled with accumulated sediment. The irrigation water reached the command area after flowing over 9 kilometers through a mostly earthen canal (only $0.5 \mathrm{~km}$ is lined). It proved impossible for the scheme's beneficiaries to remove the accumulated sediments from the 9 kilometer-long canals each year. Another complicating factor was formed by the submerged pipe close to the river intake of the scheme. This pipe was prone to blockage by accumulated sediments and proved impossible to clean.

The Ejersa scheme comes in the second position regarding its vulnerability to sedimentation. It suffers from a heavy sediment load. However, the Ejersa scheme users are well organized, with a strong water user committee capable of keeping the scheme functional. While the scheme is irrigating its full command area, the amount of labor that is required to clean the canals each season is considerable. About $68 \%$ of the lined canals and $84 \%$ of the unlined canals were found filled with sedimentation in 2019 before the start of the irrigation season (Figure 2). The farmers removed the accumulated sediment before the beginning of the irrigation season in September. Moreover, the farmers clean the scheme every month to keep it operating at full potential. The accumulated sediment load in the canal network was observed to be heavier at the furthest point from the intake, showing a tendency for suspended sediments to settle as current flow velocity dwindles.

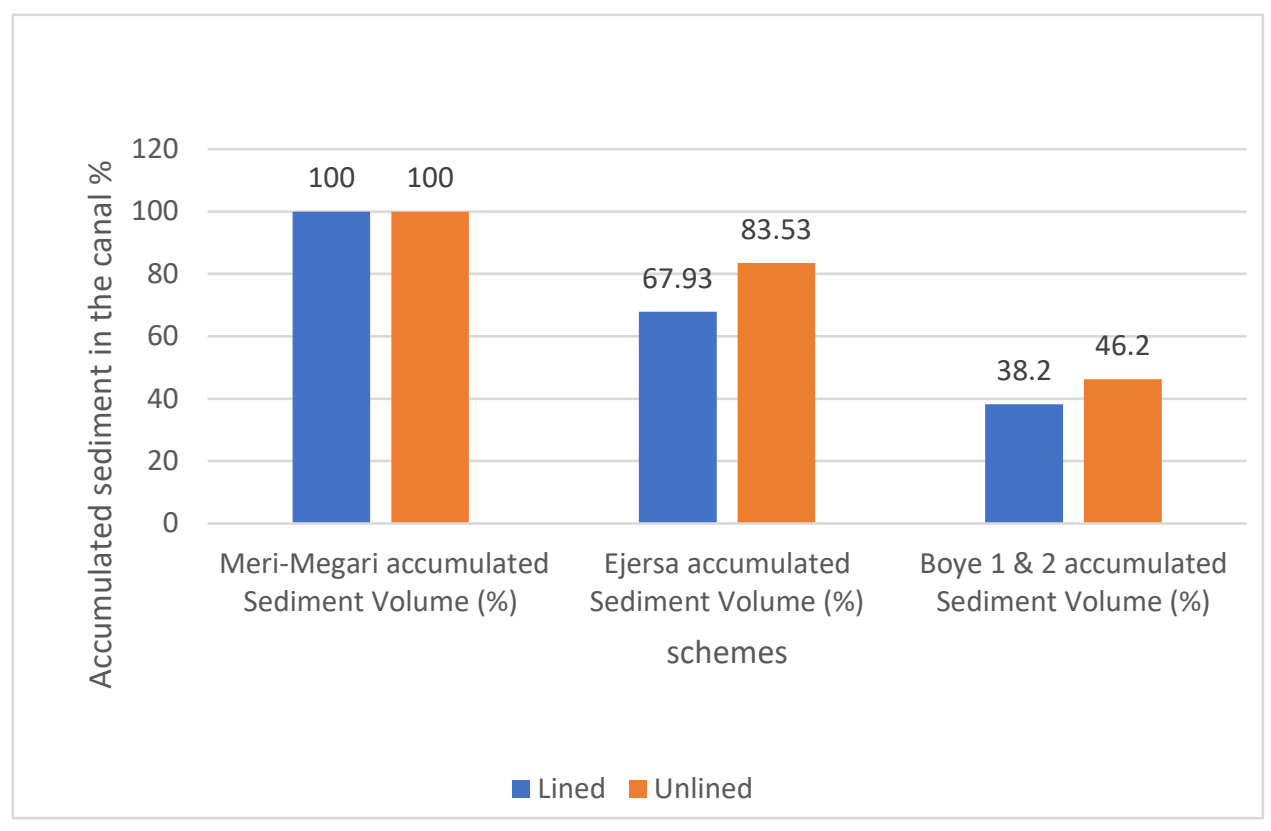

Figure 2. Percentage of accumulated sediment in the canal at the start of the irrigation season in three schemes. (Source: own measurements, 2019.) (Page: 11 The accumulated sediment in Meri-Megari scheme was observed after 3 years of abandonment. For the Kulit scheme, we could not measure the accumulated sediment before irrigation season because of the challenges in road access (muddy roads) after the rainy season.)

The Kulit traditional scheme was constructed on the same river as the abandoned MeriMegari scheme. The sediment inflow in the canal is such that the irrigation beneficiaries have to clean the canal network at least three times a year. The canal cleaning for the first irrigation season of each year consumes up to a month of labor. Any subsequent cleaning for the other two seasons takes up to 12 days. Some farmers use only two irrigation seasons a year by extending the time that the plant stays on the field, and some of the farmers use three irrigation seasons- two seasons to plant different crops and one season to transplant seeds from 45-60 days for the next season. The advantage of this scheme is that during summer when the diversion of the scheme gets washed away, the accumulated sediment inside the weir is removed without entering the scheme's canal network. However, the subsequent re-construction of the intake weir at the end of the rainy season is not easy nor 
cheap for the farmers. The re-construction and sediment removal process at the start of the next irrigation season takes a month with almost all 29 members participating.

The merged Boye 1 and 2 schemes were selected as a case study of a lightly sedimented irrigation venture, wherein the sediment inflow through the intake was insignificant during the irrigation season. However, the sediment accumulated still represented $38 \%$ of the volume of the lined main canal and $46 \%$ of the unlined canal network before the start of the first irrigation season in 2019 (Figure 2). Furthermore, the farmers clean the canal length three times a year to remove the sediment that accumulates in the canal network during the irrigation season.

\subsection{Sources of Sediment in All Study Schemes}

In all study schemes, we assessed the sources of sedimentation. We measured the accumulated sediments at the start of the irrigation season due to soil erosion from the upper river catchment, the overland flow contribution during the rainy season, removed sediment backflow from either side of the canal due to livestock interaction during the irrigation season, livestock grazing over the canal bank and drinking water from the canal during irrigation season, and finally, the livestock farmers' contribution through trespassing inside and outside the scheme.

\subsubsection{The Overland Flow of Agricultural Land}

Overland flow contribution on agricultural land during the rainy season and soil erosion in the upper catchment at the beginning of the irrigation season was found to be the major sediment source of the small-scale irrigation schemes [13]. Overland flow in agricultural areas, particularly land that is susceptible to soil erosion due to livestock trampling during the rainy season, potentially contributes to sediment accumulation. Furthermore, overland flow is one of the causes of the backflow of sediment from the sides of the irrigation canals where removed sediment is deposited on the canal banks.

\subsubsection{Soil Erosion in the Upper Catchment}

Upstream soil erosion is another sediment source caused by sediment-laden water from the upper catchment entering the canal system through the intake structure at the beginning of the irrigation season [12]. To reduce sediment entering through the intake gate, irrigators delay the canal opening by 2-3 weeks, delaying the growing season [6] (p. 9).

While these results confirm the existence of the sources of sedimentation that are frequently highlighted in both the neo-Malthusian and technical discourses (as described in Section 2), in the next section we will highlight the importance of an often-overlooked third cause: livestock.

\subsection{Livestock-Irrigation Scheme Interaction as a Major Sediment Contributor during the Irrigation Season}

Before and during the irrigation seasons, livestock grazing and movements in and out of the schemes contribute to sediment in all four irrigation schemes. Livestock production is the second most important economic activity in the area and a key means of livelihood for many. The type and number of livestock holdings of the respondents vary across the study areas from 0 to 33 heads per household and over $70 \%$ of the livestock are cattle.

The land that was used to construct the irrigation scheme and the remaining grazing land was owned by livestock farmers (LFs). During the upgrading of the Ejersa and Boye 1 and 2 schemes, there were two agreements: one with the irrigators regarding the land that was going to be used for canal construction with adequate compensation for the land, and a second agreement with government officials regarding measures in the scheme to facilitate the use for livestock and livestock farmers (LFs). The government agreed to construct cattle troughs along the canal and a bridge to help the livestock and livestock farmers in exchange for their consent to the construction. The agreed measures implicitly indicate that the livestock was expected to drink from the canal. However, the government representative office did not honor the agreement and the cattle troughs and the bridge 
were not constructed. On top of that, during the scheme modernization, the canal route changed its original path, and the canal depth was shallower than in the traditional scheme. Consequently, the water overtops the canal and creates a water stagnation on the grazing land. The livestock farmers were disappointed because promises were not kept. However, the government officials who were in favor of the scheme construction ignored the livestock farmers' objections. In turn, the livestock farmers felt threatened by the government officials who favored irrigation over livestock farming and they felt they were losing their property rights over the water resource.

In the absence of troughs, livestock struggle to drink from the canal when the water level is low. The livestock farmers see the absence of cattle troughs as a denial of water rights for their livestock, and they still have a lingering feeling that the land they have already given for the irrigation scheme belongs to them. Excluding the livestock from the irrigation scheme is extremely difficult because the grazing lands are located along the irrigation canal. The scheme neither has a clear boundary that forbids the livestock farmers to keep their livestock away from the scheme nor a fence that prevents livestock interaction with the irrigated land.

In all study areas, grazing land is located along the irrigation canals, mostly on the riverbed side. Irrigation water flows a long distance to reach the command area and along the trajectory of the canals—in some cases, on both sides of the canal-grazing areas are located, accommodating hundreds of livestock. In most parts of the country in peri-urban areas, drinking water for livestock was never considered in urban planning. Consequently, livestock is forced to drink canal water or water from the river [31]. In all the studied irrigation schemes, there are no cattle troughs along the canal for the livestock to drink in a safe, non-disturbing way and no water supply sources in case the river is low. The absence of the troughs gives the livestock access to everywhere along the canal length and as a result, they push the sediment into the canal and destroy the canal bank (Figure $3 b$ ). Uncontrolled access to the grazing land on the canal bank and cattle trampling all around the scheme make the land more vulnerable to soil erosion and leads to an increase in sedimentation [16]. The lack of dedicated safe access points for cattle aggravates vulnerability of soil erosion $[18,32,33]$. By frequently crossing the irrigation canals (Figure 3a), cattle push deposited sediment into the canal, damage the canal banks, and cause bank erosion that leads to sedimentation in the canal [34].

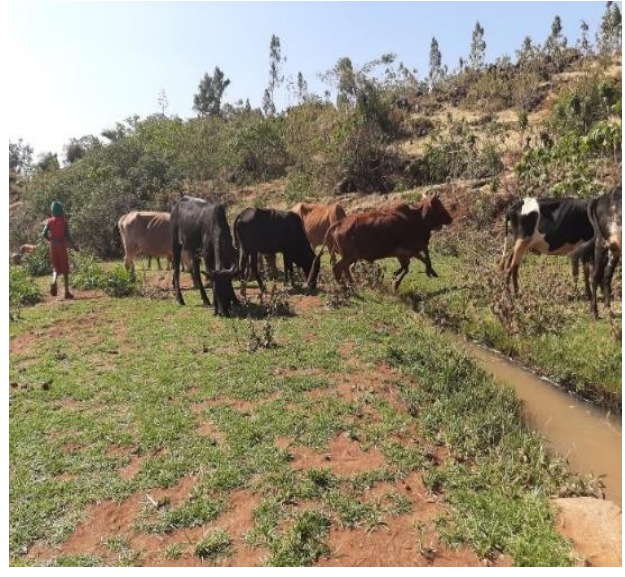

(a)

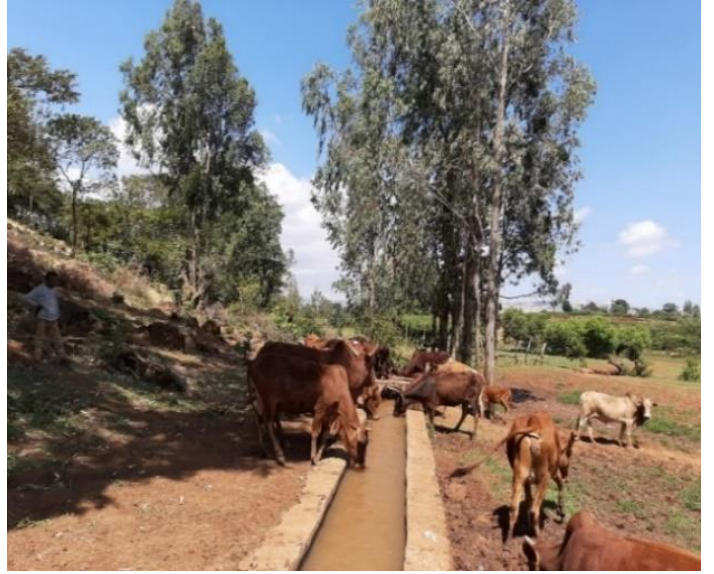

(b)

Figure 3. (a) Cattle grazing and crossing the canal. (b) Cattle drinking from the canal. (Source: Ejersa scheme pictures by Hanan Tadele, 2019.)

A common practice among the livestock farmers is to put local material in the canal to block and raise the water level for the livestock to drink safely. The herders who construct the blockage never remove the material once the cattle have had their fill, thus disturbing 
irrigation water supply and, perhaps more importantly, creating local hubs for sediments to accumulate (Figure $4 a, b)$.

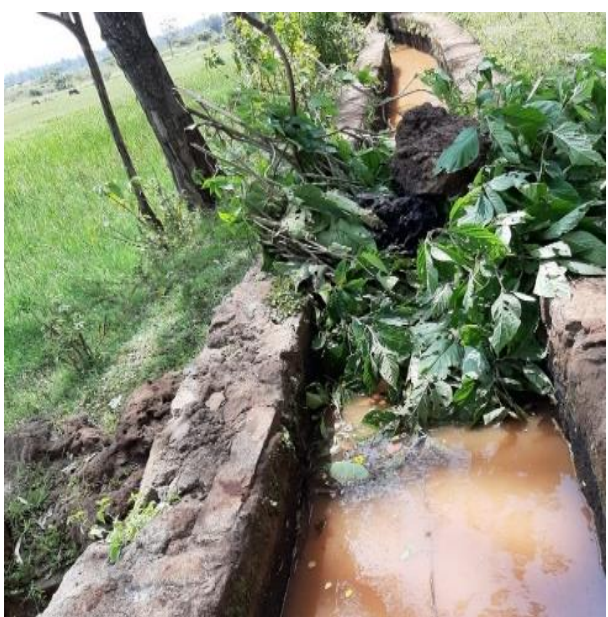

(a)

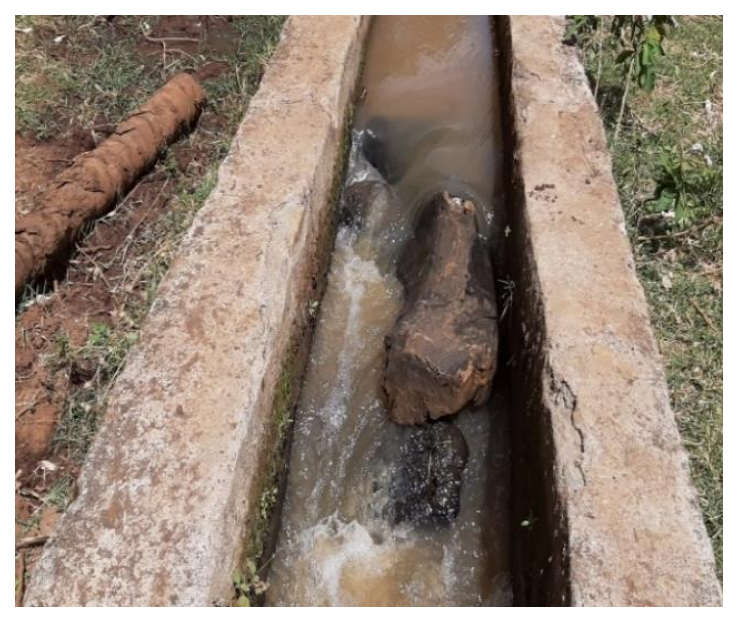

(b)

Figure 4. (a,b). Canals blocked by local material in Ejersa scheme. (Source: pictures by Hanan Tadele, 2019.).

Livestock are owned by three different groups of farmers: (1) livestock farmers who are irrigators in several irrigation schemes, (2) livestock farmers who use the same irrigation scheme, and (3) trespassing livestock farmers who do not have land inside the irrigation schemes but whose rainfed farmland is located along the grazing land. Even though some of the livestock farmers are users of the small-scale irrigation scheme, emerging conflicts over damage caused by livestock are difficult to solve. Livestock farmers belong to different owner groups with different needs and different levels of attachment to irrigated land. Moreover, irrigators and livestock farmers are represented by two different institutions: the Irrigation Water User Association (WUA) and Livestock Farmers Association (LFA), both working for the benefit of their members without considering the damage that they cause to each other. Lastly, boundary issues between the grazing land and the irrigation scheme territory are unsettled. Without a defined boundary between these two communal resources, it remains challenging for the institutions to solve problems by themselves.

Livestock owners who gave up land for the construction of the scheme, but do not have land inside the irrigation scheme, feel short-changed. They contributed to the scheme but are excluded from the benefits created by the irrigation scheme. They expressed their reluctance of caring for the schemes, and they are not bothered by their contribution to scheme sedimentation or canal bank destruction by livestock. They do not feel ownership of the scheme. Instead, they prefer to freely graze their livestock in all grazing areas. Furthermore, they believe they have nothing to lose if the scheme is damaged. On the contrary, when the system breaks down, they gain access to the entire grazing land and thus they seek to reduce the risk of the livestock getting hurt trying to drink from the canal. In fact, they admitted that they tried to damage the intake gate. They did not succeed so far, but indicated that they would continue trying to destroy it without being directly responsible to avoid the consequences of destruction of government property (LF focus group discussion in Ejersa, Waliso, November 2019.)

A livestock farmer who also used the same irrigation schemes (Boye and Ejersa) stated in an interview that they preferred not to speak about the problem, as they believed that the problem is complicated for them to solve unless government officials get involved. One of them believed that both parties, livestock farmers and the irrigators, were right because for both groups it was a question of survival. Neither livestock nor crops can survive without water and it is just a conflict of interest that may not be solved easily. Since no solution was in sight, as a livestock owner and irrigation user, they neither opposed the consequences 
of livestock-irrigation interaction nor did they support the irrigators' effort to limit the interaction. They acquiesced in letting their cattle at the canal bank graze and drink the water, even though they were aware that cattle contribute to sedimentation and canal bank damage. They were willing to contribute the money and labor like other irrigators to maintain the scheme and let their livestock graze as any LF does (LFs interview, Waliso, November 2019).

Both irrigators and livestock farmers have an association that was formed under the acknowledgment of the district office. These two associations have not agreed on any form of cooperation regarding communal resource use. The WUA admits that the LFs are the owners of the grazing land and thus they have decision power over the use of grazing land that includes the verge of irrigation scheme canal bank. However, the irrigators believe that they should at least decide about the irrigation scheme usage, water supply, and any harm that may affect the scheme. Yet, they are not in a position to do so due to the livestock drinking water from canals, which has a negative impact on the irrigation water supply and distribution. The WUA feels it has no means of controlling the situation.

Livestock farmers who do not benefit from the irrigation scheme emphasized that it has been their grazing land: the irrigators are the ones who appropriated the grazing land and created problems for the livestock and livestock farmers. If the scheme had not been constructed, their livestock would have had safe access to drinking water. The existence of clearly defined boundaries of resource systems is often mentioned as a crucial factor for sustainable governance of local commons [35]. Yet none of the small-scale irrigation schemes in our study have rules and regulations that can be applied to all scheme users, irrigators, livestock farmers, and trespassers. The Ejersa and Boye 1 and 2 LFs demanded that their presence be acknowledged for them to be able to cooperate with irrigators and contribute to the scheme's sustainability. This can be achieved by constructing a cattletrough and a bridge. Meri-Megari LFs are using the irrigation canal as a grazing area since it is abandoned and filled with grass. The Kulit scheme is a traditional scheme and they have not yet approached the government office to upgrade the system, and the cattle drink the water without cattle troughs and sometimes by walking in the canal.

Because of the conflict of interest and the boundary issue of the communal resource, the Water User Association (WUA) and Livestock Farmers Association (LFA) were unable to solve their differences. Government officials claim they were unable to help since there is no assigned specific body in the district office that deals with the issue related to boundaries. As a result, damage caused by the livestock interactions with irrigation schemes continued. Nevertheless, since both associations (WUA and LFA) fall under the district irrigation development office, it is formally responsible to smoothen the relationship between the two groups to reduce the damage. Both the WUA and LFA had been raising their complaints, yet the LFA still believed they were not important enough to warrant the district officers' attention. This neglect slighted them and hardened their unwillingness to co-operate with irrigators.

Complicating matters further are the frequent changes in government policy and district office structure. The mandate of those responsible for small-scale irrigation changes, while the officers who have experience in the specific place are frequently assigned to different locations. As a result, the district offices are facing a lack of skilled and experienced manpower.

Gaining the trust from irrigators as well as livestock farmers takes a long time. The few officers who did win those farmers' trust often got re-assigned, thus exacerbating the communication problem between the farmers and the district office. Moreover, understaffing, missing documents due to the frequent change of the officers, shortage of skilled manpower, a lack of coordination, and a low level of participation and consultation with the schemes make the problem more challenging to handle for the district office. 


\subsection{Quantity of Sediment Deposition in Ejersa Scheme during the Irrigation Season}

The Ejersa scheme is one of the schemes that faces a challenge of sedimentation caused by strong livestock disturbance due to livestock grazing along the canal bank. It causes a significant sediment deposition in the canal during the irrigation season. In this scheme, 60 households use the grazing land along the main canal. On average, a household has about 11.93 livestock with a standard deviation of 7.4 [26] per household involving mostly cattle. On average, over 600 heads of livestock graze along the canal banks every day. They cross the canals frequently, pushing the sediment into the canal (Figure 3a).

Furthermore, lacking cattle troughs along the irrigation canal, the canal is the only means of drinking water supply for the livestock when the river is low (Figure 3b). The livestock farmers put blocking barriers consisting of local material inside the canal to raise the water level for the livestock to drink safely. The cattle farmers raise the water level to $163 \%$ by adding those materials (Figure $4 a, b$ ).

The sediment inflow to the Ejersa irrigation scheme was measured weekly at eight points along the $1.85 \mathrm{~km}$ of lined main intake canal. The sediment inflow level varies from one data collection point to another. Figure 5 shows a variation in sediment concentration across the data collection stations; the maximum and minimum sediment concentrations were found in different stations due to livestock disturbances. The minimum sediment inflow per cubic meter per second was observed in the fourth station for the first 4 weeks followed by station two from week four to week eight, and from week 8-16, the minimum sediment inflow was observed at the first station or the intake.

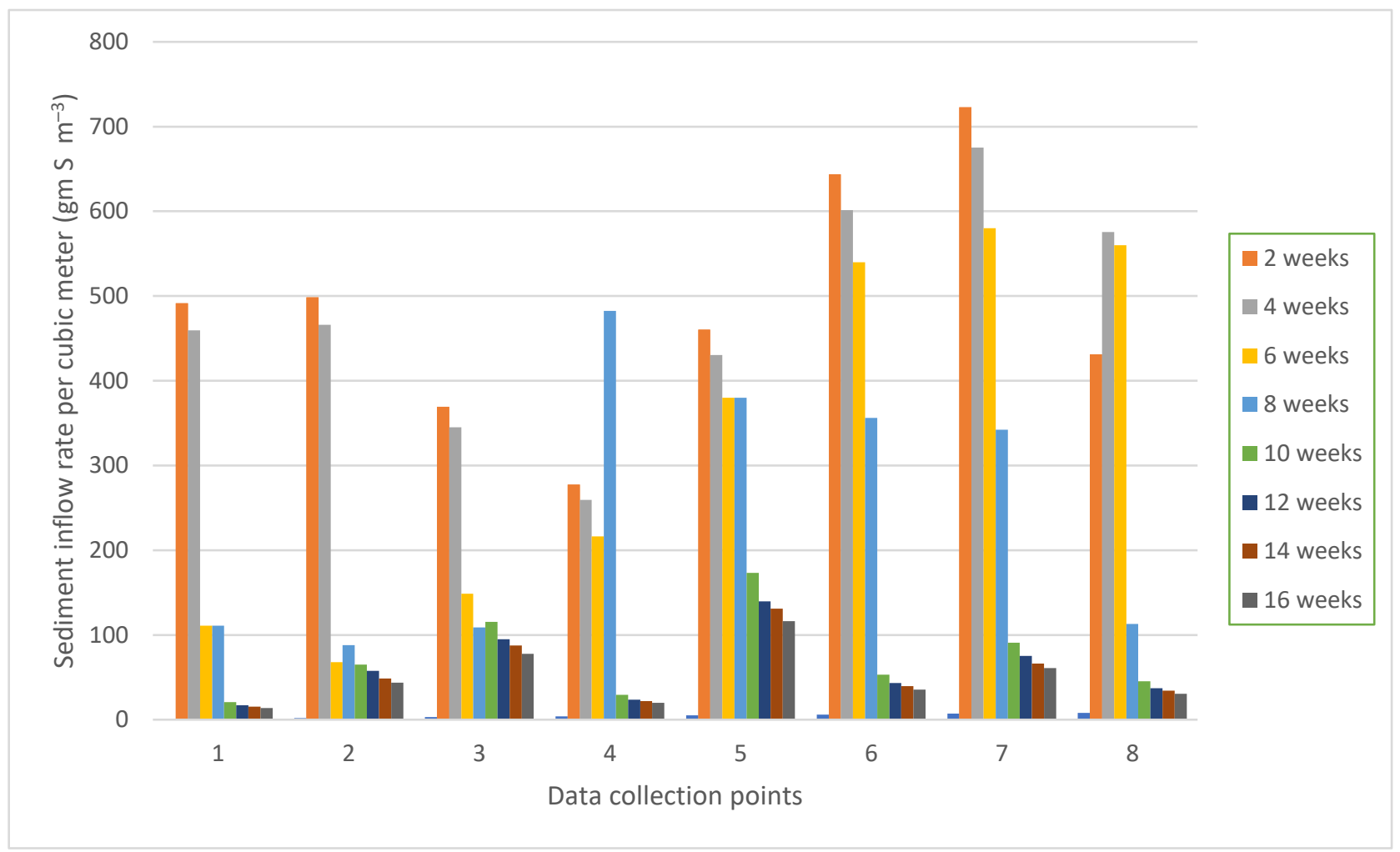

Figure 5. Sediment inflow per 2 weeks at data collection points (from intake (data collection point 1 ) to most downstream along the main canal (point 8)).

However, the maximum sediment inflow per cubic meter per second was observed at the seventh station for the first 6 weeks, followed by station six for the first 4 weeks. Higher sediment inflow was measured at the point downstream of the livestock grazing and drinking point during the disturbance compared with the upstream of the access point [34]. The livestock disturbance was primarily observed at a certain distance from the intake. In some cases, the disturbance occurred at the weir of the scheme: the livestock 
re-suspend the deposited sediment while drinking the water or crossing the grazing area through the weir. Other times, swimming kids at the weir intake re-suspend the sediment and then relatively higher concentrations are found at the intake than other consecutive data collection points.

The trend of Figure 6 shows that during the irrigation season, the sediment inflow rate per cubic meter increases from the intake to the furthest point and the sediment concentration spike was found at the place where there was a disturbance. Moreover, the inconsistencies in peaks demonstrate that rather than sediments originating from upstream catchment erosion, disturbances caused by livestock and swimming kids explain the values at any point along the canal during the irrigation season. Moreover, it also shows a reduction in sediment concentration over time. The possible reasons might be that the quantity of water that arrives at the Ejersa scheme reduces significantly since the Ejersa scheme is the fifth scheme that has been constructed on the same river, and as a result, the sediment concentration that is carried by the water would be less. Discharge and sediment concentration show a direct correlation. The other possible reason is that the kids who swim at the intake and re-suspend the sediment at some point stop swimming because the water level at the intake is too low to swim in. As a result, the disturbance would be less and thus sediment concentration in the canal is reduced.

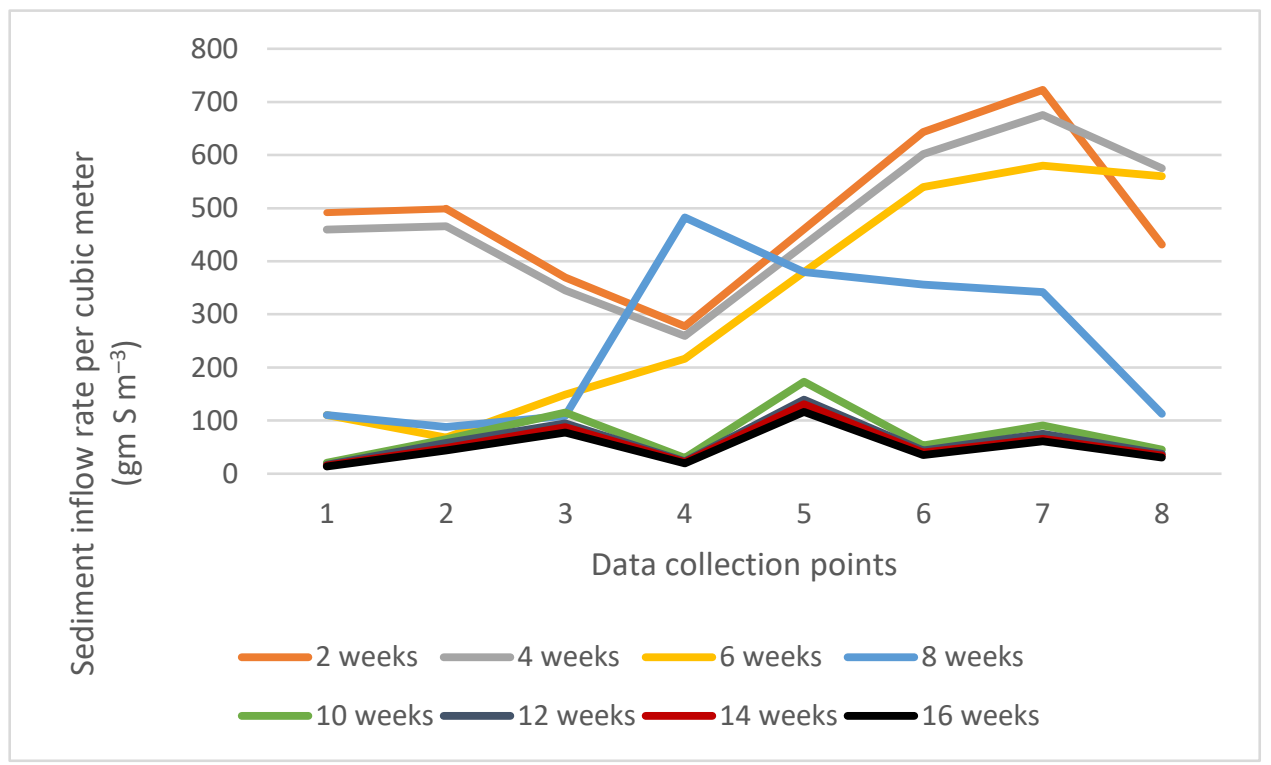

Figure 6. Sediment inflow trend lines per 2 weeks at data collection points (from intake (point 1) to most downstream along the main canal (point 8)).

\section{Conclusions and Recommendations}

Since the discourse around sedimentation of SSI schemes is based on erroneous assumptions regarding its cause, it is unsurprising that the remedies that have been tried in the past proved ineffective. The focus of the dominant discourse is on upstream catchment protection, neglecting both protection against soil erosion through overland flow along the margins of the canal network and sedimentation caused by livestock drinking from the canals and through disturbances caused by livestock grazing and trespassing. Hence, remedies that have been advocated in the past, such as the design and construction of silt traps at the start of the main canal and conservation measures in the upstream river catchment, will not be sufficient to deal with ongoing sedimentation during the irrigation season.

One of the issues that the schemes are facing as a livestock-scheme interaction is a boundary issue between the grazing area and the SSI's margin of the canal network. It is a complicated matter, especially since there is no specific government body at the small-scale irrigation level that can solve the boundary-related problems. Lacking an easy solution, the 
problem of sedimentation and damage of SSI infrastructure caused by livestock interaction during the irrigation season has been sustained.

Livestock-irrigation interaction contributes to sedimentation and canal bank damage. It also affects the water supply since the livestock are considerable water consumers, while upstream users also withdraw water for domestic use.

To promote sustainable management of small-scale irrigation infrastructure and improve irrigation water supply, the government has a rule that a water committee must be established before the construction of water infrastructure. However, so far, this involves irrigators only. It is suggested that involving livestock farmers in the water user committee or creating WUA committees that comprise at least two sub-committees, livestock farmers and irrigators from the beginning of the scheme design and construction, might help to resolve some of the conflicts related to the livestock-irrigation conundrum. Being represented would give livestock farmers a sense of ownership and involvement that might commit them to resolving the negative impact of livestock-irrigation interactions. Joint rule-making by irrigators and livestock owners concerning the use of grazing land, use of canals for drinking, and movements of livestock across canal infrastructure may help to mitigate the sedimentation as a result of livestock interactions.

Boundary policy efforts that seek to integrate both livestock and irrigation farming systems will be necessary to achieve improvements. This calls for a new institutional approach on the part of government agencies, abolishing established "silo" structures to facilitate the integration of livestock and irrigated production. Improving the sediment management strategy can make an important contribution to increasing overall agricultural water productivity and improve the performances of SSI schemes, which are believed to be essential to sustainably meeting future human food security needs and reducing poverty.

Author Contributions: Data collection, H.T.D.; formal analysis, H.T.D. and A.B.; writing-original draft preparation, H.T.D.; writing-review and editing, A.B., C.d.F., and M.A.; supervision, A.B. and C.d.F. All authors have read and agreed to the published version of the manuscript.

Funding: This research was conducted in the framework of the "Capacity Development of Higher Education Institutions in Small-Scale Irrigation (and Micro Irrigation)" project (Nuffic/Niche/Eth/197) funded by the governments of Ethiopia and the Netherlands. The project was implemented by Arba Minch University, Ethiopia, in cooperation with the IHE Delft Institute for Water Education and Wageningen University and Research Centre, both in the Netherlands.

Institutional Review Board Statement: Not applicable.

Informed Consent Statement: Not applicable.

Data Availability Statement: The data presented in this study are available on request.

Acknowledgments: The authors are very grateful to Arba Minch University, Ethiopia, Wageningen University, and Research Centre, IHE Delft Institute for Water Education, NUFFIC, Dutch organization for internationalization in education, for the PhD scholarship, The Hague, Netherlands. We also thank the Oromia irrigation development agency, south-west Shoa zone of Oromia, Waliso, and Ameya district irrigation development office. We especially acknowledge the WUA Committees, livestock farmers associations, and farmers who kindly participated in the research.

Conflicts of Interest: The authors declare no conflict of interest.

\section{References}

1. Makombe, G.; Namara, R.; Hagos, F.; Awulachew, S.B.; Ayana, M.; Bossio, D. A Comparative Analysis of the Technical Efficiency of Rain-Fed and Smallholder Irrigation in ETHIOPIA; IWMI: Colombo, Sri Lanka, 2011; Volume 143.

2. Hanjra, M.A.; Gichuki, F. Investments in agricultural water management for poverty reduction in Africa: Case studies of Limpopo, Nile, and Volta river basins. Nat. Resour. Forum 2008, 32, 185-202. [CrossRef]

3. Lambisso Wamiso, R. Assessment of design practices and performance of small scale irrigation structures in south region, MSc Thesis. Int. Water Manag. Inst. (IWMI) 2008, 47-57. [CrossRef]

4. Awulachew, S.B.; Ayana, M. Performance of Irrigation: An Assessment at Different Scales in Ethiopia. Exp. Agric. 2011, 47, 57-69. [CrossRef] 
5. Santosh Pingale, N.W. Evaluation of Failures and Design Practices of River Diversion Structures for Irrigation: A Revisit of Two SSI Schemes in Ethiopia. Int. J. Earth Sci. Eng. Int. J. Earth Sci. Eng. 2017, 10, 495-505. [CrossRef]

6. Gurmu, Z.A.; Ritzema, H.; de Fraiture, C.; Ayana, M. Stakeholder roles and perspectives on sedimentation management in small-scale irrigation schemes in Ethiopia. Sustainability 2019, 11, 6121. [CrossRef]

7. Tamene, L.; Park, S.; Dikau, R.; Vlek, P. Analysis of factors determining sediment yield variability in the highlands of northern Ethiopia. Geomorphology 2006, 76, 76-91. [CrossRef]

8. Kidane, D.; Alemu, B. The effect of upstream land use practices on soil erosion and sedimentation in the Upper Blue Nile Basin, Ethiopia. Res. J. Agric. Environ. Manag. 2015, 4, 55-68.

9. Gelagay, H.S.; Minale, A.S. Soil loss estimation using GIS and Remote sensing techniques: A case of Koga watershed, Northwestern Ethiopia. Int. Soil Water Conserv. Res. 2016, 4, 126-136. [CrossRef]

10. Munir, S. Role of Sediment Transport in Operation and Maintenance of Supply and Demand Based Irrigation Canals: Application to Machai Maira Branch Canals: UNESCO-IHE PhD Thesis; CRC Press: Boca Raton, FL, USA, 2011.

11. Theol, S.A.; Charlotte de Fraiture, F. Understanding Cohesive Sediments Behaviour In Irrigation Canals Using Delft $3 d$ Model Simulation. In Proceedings of the 2nd World Irrigation Forum, Chiang Mai, Thailand, 6-8 November 2016.

12. Dereje, B.; Yusuf, K. Determining sediment load of Awash River entering into Metehara sugarcane irrigation scheme in Ethiopia. J. Environ. Earth Sci. 2015, 5, 110-117.

13. Wolancho, K.W. Watershed management: An option to sustain dam and reservoir function in Ethiopia. J. Environ. Sci. Technol. 2012, 5, 262-273. [CrossRef]

14. Kassie, A.E. Challenges and Opportunities of Irrigation Practices in Ethiopia: A Review. J. Eng. Res. Rep. 2019, 9, 1-12. [CrossRef]

15. Haregeweyn, N.; Tsunekawa, A.; Poesen, J.; Tsubo, M.; Meshesha, D.T.; Fenta, A.A.; Nyssen, J.; Adgo, E. Comprehensive assessment of soil erosion risk for better land use planning in river basins: Case study of the Upper Blue Nile River. Sci. Total Environ. 2017, 574, 95-108. [CrossRef]

16. Wilson, R.T. Perceptions, practices, principles and policies in provision of livestock water in Africa. Agric. Water Manag. 2007, 90, 1-12. [CrossRef]

17. Descheemaeker, K.; Amede, T.; Haileslassie, A. Improving water productivity in mixed crop-livestock farming systems of sub-Saharan Africa. Agric. Water Manag. 2010, 97, 579-586. [CrossRef]

18. O'Callaghan, P.; Kelly-Quinn, M.; Jennings, E.; Antunes, P.; O'Sullivan, M.; Fenton, O.; Huallachain, D.O. The environmental impact of cattle access to watercourses: A review. J. Environ. Qual. 2019, 48, 340-351. [CrossRef]

19. Kairis, O.; Karavitis, C.; Salvati, L.; Kounalaki, A.; Kosmas, K. Exploring the impact of overgrazing on soil erosion and land degradation in a dry Mediterranean agro-forest landscape (Crete, Greece). Arid Land Res. Manag. 2015, 29, 360-374. [CrossRef]

20. Steinfeld, H.; Wassenaar, T.; Jutzi, S. Livestock production systems in developing countries: Status, drivers, trends. Rev. Sci. Tech. 2006, 25, 505-516. [CrossRef]

21. Zaimes, G.N.; Schultz, R.C. Stream bed substrate composition adjacent to different riparian land-uses in Iowa, USA. Ecol. Eng. 2011, 37, 1692-1699. [CrossRef]

22. Vidon, P.; Campbell, M.A.; Gray, M. Unrestricted cattle access to streams and water quality in till landscape of the Midwest. Agric. Water Manag. 2008, 95, 322-330. [CrossRef]

23. Madden, D.; Harrison, S.; Finn, J.A.; Huallacháin, D.Ó. The impact of cattle drinking points on aquatic macroinvertebrates in streams in south-east Ireland. Ir. J. Agric. Food Res. 2019, 58, 13-20. [CrossRef]

24. Tolera, T. The Problems, Opportunities and Implications of Small Scale Irrigation for Livelihood Improvement in Ethiopia-A Review. Civ. Environ. Res. 2017, 9, 27-34.

25. Haile, G.G.; Kasa, A. Irrigation in Ethiopia: A review. Acad. J. Agric. Res. 2015, 3, 264-269.

26. Design-Document, U. Ejersa Small Scale Diversion Irrigation Project; Oromia Water, Mineral \& Energy Bureau: Addis Ababa, Ethiopia, 2013.

27. Design-Document, U. Boye Small Scale Diversion Irrigation Project; Oromia Water, Mineral \& Energy Bureau: Addis Ababa, Ethiopia, 2013.

28. Glaser, B.G.; Strauss, A.L. Discovery of Grounded Theory: Strategies for Qualitative Research; Routledge: New Brunswick, NJ, USA, 2017.

29. Bernard, H.R.; Bernard, H.R. Social Research Methods: Qualitative and Quantitative Approaches; Sage: Gainesville, FL, USA, 2013.

30. Bartram, J.; Ballance, R. Water Quality Monitoring: A Practical Guide to The Design and Implementation of Freshwater Quality Studies and Monitoring Programmes; CRC Press: Boca Raton, FL, USA, 1996.

31. Sileshi, Z.; Tegegne, A.; Tsadik, G.T. Water resources for livestock in Ethiopia: Implications for research and development. Integr. Water Land Manag. Res. Capacit. Build. Priorities Ethiop. 2003, 66, 66-77.

32. Brits, J.; Van Rooyen, M.; Van Rooyen, N. Ecological impact of large herbivores on the woody vegetation at selected watering points on the eastern basaltic soils in the Kruger National Park. Afr. J. Ecol. 2002, 40, 53-60. [CrossRef]

33. O' Sullivan, M.; Huallacháin, D.Ó.; Antunes, P.O.; Jennings, E.; Kelly-Quinn, M. The impacts of cattle access to headwater streams on hyporheic zones. Biol. Environ. 2019, 119B, 13-27. [CrossRef] 
34. O'Sullivan, M.; Óh Uallacháin, D.; Antunes, P.O.; Jennings, E.; Kelly-Quinn, M. The impacts of cattle access points on deposited sediment levels in headwater streams in Ireland. River Res. Appl. 2019, 35, 146-158. [CrossRef]

35. Ostrom, E. Governing the Commons: The Evolution of Institutions for Collective Action; Cambridge University Press: Cambridge, UK, 1990; pp. 58-101. 